\title{
Trade Liberalisation and 'Fair \\ Trade' Demands: Addressing the Environmental and Labour Standards Issues
}

\author{
Jagdish Bhagwati
}

\section{INTRODUCTION}

$\mathcal{1}$ have long enjoyed an intellectual affinity with Sir Leon Brittan. He is the rare politician who reads what academic economists write - I have had the pleasure of many friends telling me about occasions when he quoted approvingly from my own writings - has a commitment to freer trade, and is astute enough to translate that commitment into concrete action.

In what I say below, therefore, I find myself in the unusual situation of disagreeing with what I see as the main policy thrust of his remarks though of course Professor André Sapir will welcome the fact that the debate is joined explicitly and forcefully in the opening session itself.

In the following I propose to argue why many of the demands, emanating principally from the rich countries, for imposing 'higher' environmental and labour standards on the poor countries as preconditions for trade liberalisation, ought to be rejected. Since practical policymaking cannot ignore political realities while statesmanship simultaneously requires that these realities must be confronted creatively and in a principled way, I suggest alternative ways in which these demands, which are politically salient as Sir Leon Brittan correctly observes, can be channelled into policy proposals that are better crafted and more consonant with the principles of free trade.

JAGDISH BHAGWATI is the Arthur Lehman Professor of Economics and Professor of Political Science at Columbia University. This is the longer text on the basis of which remarks were made at the Symposium on December 8, 1994 at Université Libre de Bruxelles in the opening session in which Sir Leon Brittan also participated. The author has drawn liberally on the 1994 Wincoot Lecture which he gave in London recently. 


\section{WHY HAVE DEMANDS FOR FAIR TRADE ARISEN?}

The demands for imposing environmental and labour standards on the poor countries reflect several factors. Let me mention just a few of the more compelling ones that bear on the environmental and labour standards questions, ${ }^{1}$ while addressing their merits later.

First, the fierce competition as the world economy gets increasingly globalised has led to increased sensitivity to any domestic policy or institution abroad that seems to give one's foreign rivals an extra edge. If then a country's producers have lower environmental and labour regulatory burdens, that is objected to as 'unfair'.

Second, protectionists see great value in invoking 'unfairness' of trade as an argument for getting protection: it is likely to be more successful than simply claiming that you cannot hack it and therefore need protection. This has made the diversity of burdens for an industry among different countries appear illegitimate, making demands to reduce it look like a reasonable alternative to overt protectionism.

Third, some in the environmental and labour movements worry about the effect that competition with 'Lower'-Standards countries will have on their own standards. If trade shifts activity to where the costs are lower because of lower standards, and if additionally capital and jobs move away to exploit lower standards abroad, then the countries with higher standards may be forced to lower their own.

Fourth, aside from these 'economic' and political concerns focused on their own society, the environmental and, especially, labour lobbies have moral concerns. They feel a sense of transborder moral obligation to human beings abroad: they would like child labour to cease abroad because they worry about children abroad; they do not want Mexicans to suffer from lower environmental standards; and so on.

These arguments cover a broad spectrum and are typically jumbled together in the popular and in political discourse. But they must be kept sharply distinct in our reflections and analysis if we are to arrive at proper policy judgments, as I hope to do now. Let me begin with environmental questions and then turn to labour issues, keeping in mind the proposals that are currently in the political arena.

\footnotetext{
' I have dealt with these factors systematically in my extended analysis in 'Demands to Reduce Domestic Diversity Among Trading Nations', which is Chapter 1 of Vol. 1 of the 2-volume set of studies in Jagdish Bhagwati and Robert Hudec (eds.), Fair Trade and Harmonization: Prerequisities for Free Trade?, forthcoming in February 1996. Vol. 1 is on Economic Analysis and Vol. 2 is on Legal Analysis and both are the product of a substantial Ford-Foundation-financed project under the auspices of the American Society of International Law, Washington DC.
} 


\section{THE QUESTION OF ENVIRONMENTAL STANDARDS}

Let me first distinguish between 'domestic' environmental problems, as when a country pollutes a lake which is entirely within its own frontiers, and 'global' environmental problems, when there are transborder externalities, as with the acid rain, global warming and ozone-layer problems.

I shall consider the domestic problems initially, observing at the outset that normally an economist would not expect to object to different environmental standards in the same industry in different countries (i.e. to what I will call Crosscountry Intra-industry, CCII, differences in standards, typically in the shape of pollution tax rates).

\section{a. Indefensible Demands for Eco-dumping}

The diversity of CCII standards will follow from differences in tradeoffs between aggregate pollution and income at different levels of income, as when richer Americans prefer to save dolphins from purse-seine nets whereas poorer Mexicans prefer to put people first and want to raise the productivity of fishing and hence accelerate the amelioration of Mexican poverty by using such nets. Again, countries will have natural differences in the priorities attached to which kind of pollution to attack, arising from differences of historical and other circumstance: Mexicans will want to worry more about clean water, as dysentery is a greater problem, than Americans who will want to attach greater priority to spending pollution dollars on clean air. Differences in technological knowhow and in endowments can also lead to CCII diversity in pollution tax rates.

The notion therefore that the diversity of CCII pollution standards/taxes is illegitimate and constitutes 'unfair trade' or 'unfair competition', to be eliminated or countervailed by eco- dumping duties, is itself illegitimate. It is incorrect, indeed illogical, to assert that competing with foreign firms that do not bear equal pollution-tax burdens is unfair. ${ }^{2}$ I would add two more observations:

- We should recognise that if we lose competitive advantage because we put a larger negative value on a certain kind of pollution whereas others do not is simply the flip side of the differential valuations. To object to that implication of the differential valuation is to object to the differential valuation itself, and hence to our own larger negative valuation. To see this clearly, think of a closed economy without trade. If we were to tax pollution by an industry in such an economy, its implication would be precisely that this industry would shrink: it would lose competitive advantage vis-à-vis other industries in our own country. To object to that shrinking is to object to the negative valuation being put on the pollution. There is therefore nothing 'unfair' from this perspective, if our

\footnotetext{
${ }^{2}$ This conclusion is derived and extensively defended in Bhagwati and Srinivasan (1996).
} 
industry shrinks because we impose Higher Standards (i.e. pollution taxes) on our industry while others, who value that pollution less, choose Lower Standards (i.e. pollution taxes).

- Besides, it is worth noting that the attribution of competitive disadvantage to differential pollution tax burdens in the fashion of CCII comparisons for individual industries confuses absolute with comparative advantage. Thus, for instance, in a two-industry world, if both industries abroad have lower pollution tax rates than at home, both will not contract at home. Rather, the industry with the comparatively higher tax rate will. The noise that each industry makes on basis of CCII comparisons,aggregated to total noise by all industries, is then likely to exaggerate seriously the effect of different environmental valuations and CCII differences on the competitiveness of industries in Higher-Standards nations.

But one more worry needs to be laid at rest if the demands for upward harmonisation of standards or eco-dumping duties in lieu thereof are to be effectively dismissed. This is the worry that I noted at the outset: that free trade with countries with Lower Standards will force down one's Higher Standards. The most potent of these worries arises from the fear that 'capital and jobs' will move to countries with Lower Standards, triggering a race to the bottom (or more accurately a race towards the bottom), where countries lower their standards in an inter-jurisdictional contest, below what some or all would like, in order to attract capital and jobs. ${ }^{3}$ So, the solution would lie then in coordinating the standards-setting among the nations engaged in freer trade and investment. In turn, this may (but is most unlikely to) require harmonisation among countries to the Higher Standards (though, even then, not necessarily at those in place) or perhaps there might be improvement in welfare from simply setting minimum floors to the standards.

This is undoubtedly a theoretically valid argument. The key question for policy, however, is whether the empirical evidence shows, as required by the argument, that: (1) capital is in fact responsive to the differences in environmental standards and (2) different countries/jurisdictions actually play the game then of competitive lowering of standards to attract capital. Without both these phenomena holding in a significant fashion in reality, the 'race to the bottom' would be a theoretical curiosity.

As it happens, systematic evidence is available for the former proposition alone, but the finding is that the proposition is not supported by the studies to date: there is very weak evidence, at best, in favour of interjurisdictional mobility in response to CCII differences in environmental standards. ${ }^{4}$ There are in fact

\footnotetext{
${ }^{3}$ Wilson (1996) demonstrates that there can be a 'race to the top'. This possibility is disregarded in the analysis above, as in the public discourse.

${ }^{4}$ The evidence has been systematically reviewed and assessed recently by Levinson (1996).
} 
many ways to explain this lack of responsiveness: (1) the differences in standards may not be significant and are outweighed by other factors that affect locational decisions; (2) exploiting differences in standards may not be a good strategy relative to not exploiting them; and (3) lower standards may paradoxically even repel, instead of attracting, DFI. ${ }^{5}$

While we do not have similar evidence on the latter proposition, it is hardly likely that, as a systematic tendency, countries would be actually lowering Environmental standards in order to attract capital. As it happens, countries, and even state governments in federal countries (e.g. President Bill Clinton, when Governor of Arkansas), typically play the game of attracting capital to their jurisdictions: but this game is almost universally played, not by inviting firms to pollute freely but instead through tax breaks and holidays, land grants at throwaway prices etc., resulting most likely in a 'race to the bottom' on business tax rates which wind up below their optimal levels! It is therefore not surprising that there is little systematic evidence of governments lowering Environmental standards in order to attract scarce capital. Contrary to the fears of the environmental groups, the race to the bottom on Environmental standards therefore seems to be an unlikely phenomenon in the real world.

I would conclude that both the 'unfair trade' and the 'race to the bottom' arguments for harmonising CCII standards or else legalising eco-dumping duties at the WTO are therefore lacking in rationale: the former is theoretically illogical and the latter is empirically unsupported. In addition, such WTO-legalisation of eco-dumping will facilitate protectionism without doubt. Anti-dumping processes have become the favoured tool of protectionists today. Is there any doubt that their extension to eco-dumping (and equally to social-dumping), where the 'implied subsidy' through lower standards must be inevitably 'constructed' by national agencies such as the Environmental Protection Agency in the same jurisdiction as the complainant industry, will lead to the same results, even more surely?

The 'fixing' of the WTO for environmental issues therefore should not proceed along the lines of legitimating eco-dumping. ${ }^{6}$ However, the political salience of such demands remains a major problem. One may well then ask: are there any

\footnotetext{
${ }^{5}$ These factors are analysed in Bhagwati and Srinivasan (1996).

${ }^{6}$ There are other issues. One main class relates to the current GATT restrictions, as reflected in recent GATT Panel findings as in the two Dolphin-Tuna cases involving the United States, on 'values'-inspired restrictions on imports of products using processes that are unacceptable, which will have to be clarified and will be the subject of new negotiations. My own views on the best solution to this class of problems, as also to the other main class of problems raised by environmentalists who fear that it is too easy for countries to challenge the Higher Standards which they have enacted in their own countries (an issue that was at the heart of the latest GATT Panel finding, mostly in US favour, in the EU-US case on differentially punitive US taxes and standards on higher-gasoline-useage cars) are developed at length in Bhagwati and Srinivasan (1996); unfortunately, I have no time to address them today.
} 
'second-best' approaches, short of the eco-dumping and CCII harmonisation proposals, that may address some of the political concerns at least economic cost?

b. A Proposal to Extend Domestic Standards in High Standards Countries to their Firms in Low Standards Countries, Unilaterally or Preferably through an OECD Code

The political salience of the harmful demands for eco-dumping duties and CCII harmonisation is greatest when plants are closed by one's own multinationals and shifted to other countries. The actual shifting of location, and the associated loss of jobs in that plant, magnify greatly the fear of the 'race to the bottom' and of the 'impossibility' of competing against Low Standards countries. Similarly, when investment by one's own firms is seen to go to specific countries which happen to have lower standards, the resentment gets to be focused readily against those countries and their standards. However, when jobs are lost simply because of trade competition, it is much harder to locate one's resentment and fear on one specific foreign country and its policies as a source of unfair competition. ${ }^{7}$ Hence, a second-best proposal could well be to address this particular fear, however unfounded and often illogical, of outmigration of plants and investment by one's firms abroad to Low Standard countries.

The proposal is to adapt the so-called Sullivan Principles approach to the problem at hand. Under Sullivan, US firms in South Africa were urged to adopt US practices, not the South African apartheid ways, in their operations. If this principle that the US firms in Mexico be subject to US environmental policies (choosing the desired ones from the many that obtain across different states in this federal country) were adopted by US legislation, that would automatically remove whatever incentive there was to move because of environmental burden differences. ${ }^{8}$

This proposal that one's firms abroad behave as if they were at home - do in Rome as you do in New York, not as the Romans do - can be either legislated unilaterally by any High Standard country or by a multilateral binding Treaty among different High Standards countries. Again, it may be reduced to an exhortation, just as Sullivan Principles were, by single countries in isolation or by several as through a nonbinding but ethos-defining and policy-encouraging OECD Code.

The disadvantage of this proposal, of course, is that it does violate the diversity-is-legitimate rule (whose desirability was discussed by me). Investment

\footnotetext{
This, of course, does not apply equally to trade in highly differentiated products like autos where one can get fixated on specific countries, e.g. Japan.

see Bhagwati (1993).
} 
flows, like investment of one's own funds and production and trade therefrom, should reflect this diversity. It reduces, therefore, the efficiency of gains from a freer flow of cross-country investments today. But if environmental tax burden differences are not all that different, or do not figure prominently in firms' locational decisions, as the empirical literature (just cited) seems to stress, the efficiency costs of this proposal could also be minimal while gains in allaying fears and therefore moderating the demand for bad proposals could be very large indeed.

Yet another objection may focus on intra-OECD differences in High Standards. Since there are differences among the OECD countries in CCII environmental tax burdens in specific industries for specific pollution, this Proposal would lead to 'horizontal inequity' among the OECD firms in third countries. If the British burden is higher than the French, British firms would face a bigger burden in Mexico than French firms. But such differences already exist among firms abroad since tax practices among the OECD countries on taxation of firms abroad are not harmonised in many respects. Interestingly, the problem of horizontal equity has come up in relation to the demands of the poor countries (that often find it difficult to enforce import restrictions effectively) that the domestic restrictions on hazardous products be automatically extended to exports by every country. That would put firms in the countries with greater restrictions at an economic disadvantage. But agreement has now been reached to disregard the problem.

Other problems may arise: (i) monitoring of one's firms in a foreign country may be difficult; and (ii) the countries with Lower Standards may object on grounds of 'national sovereignty.' Neither argument seems compelling. It is unlikely that a developing country would object to foreign firms doing better by its citizens in regard to environmental standards (that it itself cannot afford to impose, given its own priorities, on its own firms). Equally, it would then assist in monitoring the foreign firms.

\section{c. Transborder Externalities: Global Pollution and WTO}

The preceding analysis considered the trade issues which arise between countries even when the environmental problems are purely domestic in their scope. They can arise, of course, even when these problems involve transborder spillovers or externalities. However, the latter are generally more complex. Let me consider only the problems that arise when the problem is not just bilateral (as with, say acid rain, where the US and Canada were involved) or regional, but truly global.

The chief policy questions concerning trade policy when global pollution problems are involved instead, as with ozone layer depletion and global 
warming, relate to the cooperation-solution- oriented multilateral treaties that are sought to address them. They are essentially ties into noncompliance ('defection') by members and 'free riding' by nonmembers. Because any action by a member of a treaty relates to targeted actions (such as reducing CFCs or $\mathrm{CO}_{2}$ emissions) that are a public good (in particular, that the benefits are nonexcludable, so that if I incur the cost and do something, I cannot exclude you from benefiting from it), the use of trade sanctions to secure and enforce compliance automatically turns up on the agenda.

At the same time, the problem is compounded because the agreement itself has to be legitimate in the eyes of those accused of free riding. Before those pejorative epithets are applied and punishment prescribed in the form of trade sanctions legitimated at the WTO, these nations have to be satisfied that the agreement being pressed on them is efficient and, especially, that it is equitable in burden-sharing. Otherwise, nothing prevents the politically powerful (i.e. the rich nations) from devising a treaty that puts an inequitable burden on the politically weak (i.e. the poor nations) and then using the cloak of a 'multilateral' agreement and a new WTO-legitimacy to impose that burden with the aid of trade sanctions with a clear conscience.

This is why the policy demand, often made, to alter the WTO to legitimate trade sanctions on members who remain outside of a treaty, whenever a plurilateral treaty on global environmental problem dictates it, is unlikely to be accepted by the poor nations without safeguards to prevent unjust impositions. The spokesmen of the poor countries have been more or less explicit on this issue, with justification. These concerns have been recognised by the rich nations.

Thus, at the Rio Conference in 1992, the Framework Convention on Climate Change set explicit goals under which several rich nations agreed to emission level-reduction targets (returning, more or less, to 1990 levels), whereas the commitments of the poor countries were contingent on the rich nations footing the bill.

Ultimately, burden-sharing by different formulas related to past emissions, current income, current population etc. are inherently arbitrary; they also distribute burdens without regard to efficiency. Economists will argue for burden-sharing dictated by cost-minimisation across countries, for the earth as a whole: if Brazilian rain forests must be saved to minimise the cost of a targeted reduction in $\mathrm{CO}_{2}$ emissions in the world, while the US keeps guzzling gas because it is too expensive to cut that down, then so be it. But then this efficient 'cooperative' solution must not leave Brazil footing the bill. Efficient solutions, with compensation and equitable distribution of the gains from the efficient solution, make economic sense.

A step towards them is the idea of having a market in permits at the world level: no country may emit $\mathrm{CO}_{2}$ without having bought the necessary permit from 
a worldwide quota. That would ensure efficiency, ${ }^{9}$ whereas the distribution of the proceeds from the sold permits would require a decision reflecting some multilaterally-agreed ethical or equity criteria (e.g. the proceeds may be used for refugee resettlement, UN peacekeeping operations, aid dispensed to poor nations by UNDP, WHO fight against AIDS, etc.). This type of agreement would have the legitimacy that could then provide the legitimacy in turn for a WTO rule that permits the use of trade sanctions against free riders.

\section{THE QUESTION OF LABOUR STANDARDS AND THE SOCIAL CLAUSE}

The question of labour standards, and making them into prerequisites for market access by introducing a Social Clause in the WTO, has parallels and contrasts to the environmental questions which I have just discussed.

The contrast is that labour standards have nothing equivalent to transborder environmental externalities. One's labour standards are purely domestic in scope: in that regard, the demands for 'social dumping' for lower labour standards that parallel the demands for eco-dumping have the same rationale and hence must be rejected for the same reasons.

But a different aspect to the whole question results from the fact that labour standards, unlike most environmental standards, are seen in moral terms. Thus, for example, central to American thinking on the question of the Social Clause is the notion that competitive advantage can sometimes be morally 'illegitimate'. In particular, it is argued that if labour standards elsewhere are different and unacceptable morally, then the resulting competition is morally illegitimate and 'unfair'.

Now, when this argument is made about a practice such as slavery (defined strictly as the practice of owning and transacting in human beings, as for centuries before the Abolitionists triumphed), there will be nearly universal agreement that if slavery produces competitive advantage, that advantage is illegitimate and ought to be rejected.

Thus, we have here a 'values'-related argument for suspending another country's trading rights or access to our markets, in a sense similar to (but far more compelling than) the case when the United States sought to suspend Mexico's tuna-trading rights because of its use of purse-seine nets. ${ }^{10}$ The

\footnotetext{
${ }^{9}$ This efficiency is only in the sense of cost minimisation. The number of permits may, however, be too small or too large, and getting it right by letting nonusers also bid (and then destroy permits) is bedeviled by free rider problems.

${ }^{10}$ I talk of the United States suspending Mexico's trade rights since the GATT Panel in the Dolphin-Tuna case upheld these rights for Mexico. If it had not, I should be talking simply of the United States denying market access to Mexico.
} 
insertion of a Social Clause for Labour Standards into the WTO can then be seen as a way legitimating an exception to the perfectly-sensible GATT rule that prohibits the suspension of a Contracting Party's trading rights concerning a product simply on the ground that, for reasons of morality asserted by another Contracting Party, the process by which that product is produced is considered immoral and therefore illegitimate.

The real problem with the argument, however, is that universally-condemned practices such as slavery are rare indeed. True, the ILO has many Conventions that many nations have signed. But many have been signed simply because in effect they are not binding. Equally, the United States itself has signed no more than a tiny fraction of these conventions in any case. The question whether a substantive consensus on anything except wellmeaning and broad principles without consequences for trade access in case of noncompliance can be obtained is therefore highly dubious.

Indeed, the reality is that diversity of labour practice and standards is widespread in practice and reflects, not necessarily venality and wickedness, but rather diversity of cultural values, economic conditions and analytical beliefs and theories concerning the economic (and therefore moral) consequences of specific labour standards. The notion that labour standards can be universalised, like human rights such as liberty and habeas corpus, simply by calling the "labour rights' ignores the fact that this easy equation between culture-specific labour standards and universal human rights will have a difficult time surviving deeper scrutiny.

Take the United States itself (since it is a principal proponent of the Social Clause) and one sees immediately that its labour standards are 'advanced' and that it is only providing 'moral leadership' on the question vis-à-vis developing countries, is hard to sustain and that the US logic on the question can lead the US itself into a widespread and sustained suspension of its own trading rights if there was an impartial tribunal and standing to file compliants was given to concerned citizens and NGOs rather than to governments that would be intimidated by the power of the United States from taking it to court.

Thus, for instance, worker participation in decision-making on the plant, a measure of true economic democracy much more pertinent than the unionisation of labour, is far more widespread in Europe than in North America: would we then condemn North America to denial of trading rights by the Europeans? Migrant labour is ill-treated to the level of brutality and slavery in US agriculture due to grossly inadequate and corrupt enforcement, if investigative shows on US television are a guide: does this mean that other nations should prohibit the import of US agricultural products? Sweatshops exploiting female immigrants in textiles with long hours and below-minimum wages are endemic in the textile industry, as documented amply by several civil-liberties groups: should the right of the US to export textiles then be suspended by other countries as much as the 
United States seeks to suspend the imports of textiles made by exploited child labour?

Even the right to organise trade unions may be considered to be inadequate in the US if we go by 'results', as the US favours in judging Japan: only about 12 per cent of the US labour force in the private sector is unionised. Indeed, it is no secret, except to those who prefer to think that labour standards are inadequate only in developing countries, that unions are actively discouraged in several ways in the United States. Strikes are also circumscribed. Indeed, in essential industries they are restricted: but the definition of such industries also reflects economic structure and political realities, making each country's definition only culture-specific and hence open to objection by others. Should other countries have then suspended US flights because President Reagan had broken the Air Traffic Controllers' strike?

Lest you think that the question of child labour is an easy one, let me remind you that even this raises complex questions as indeed recognised by the ILO, though not in many of the arguments heard in the United States today. The use of child labour, as such, is surely not the issue. Few children grow up even in the US without working as babysitters or delivering newspapers; many are even paid by parents for housework in the home. The pertinent social question, familiar to anyone with even a nodding acquaintance with Chadwick, Engels and Dickens and the appalling conditions afflicting children at work in England's factories in the early Industrial Revolution, is rather whether children at work are protected from hazardous and oppressive working conditions.

Whether child labour should be altogether prohibited in a poor country is a matter on which views legitimately differ. Many feel that children's work is unavoidable in the face of poverty and that the alternative to it is starvation which is a greater calamity, and that eliminating child labour would then be like voting to eliminate abortion without worrying about the needs of the children that are then born.

Then again, insisting on the 'positive-rights'-related right to unionise to demand higher wages, for instance, as against the 'negative-rights'-related right of freedom to associate for political activity, for example, can also be morally obtuse. In practice, such a right could imply higher wages for the 'insiders' who have jobs, at the expense of the unemployed 'outsiders'. Besides, the unions in developing countries with large populations and much poverty are likely to be in the urban-industrial activities, with the industrial proletariat among the better-off sections of the population, whereas the real poverty is among the nonunionised landless labour. Raising the wages of the former will generally hurt, in the opinion of many developing-country economists, the prospects of rapid accumulation and growth which alone can pull more of the landless labour eventually into gainful employment. If so, the imposition of the culture-specific developed-country-union views on poor countries about the rights of unions to 
push for higher wages will resolve current-equity and intergenerational-equity problems in ways that are normally unacceptable to these countries, and correctly so.

\section{a. The Social Clause: A Bad Idea}

One is then led to conclude that the idea of the Social Clause in the WTO is rooted generally in an ill-considered rejection of the general legitimacy of diversity of labour standards and practices across countries. The alleged claim for the universality of labour standards is (except for a rare few cases such as slavery) generally unpersuasive.

The developing countries cannot then be blamed for worrying that the recent escalation of support for such a Clause in the WTO in major OECD countries derives instead from the desire of labour unions to protect their jobs by protecting the industries that face competition from the poor countries. They fear that moral arguments are produced to justify restrictions on such trade since they are so effective in the public domain. In short, the 'white man's burden' is being exploited to secure the 'white man's gain'. Or, to use another metaphor, 'blue protectionism' is breaking out, masking behind a moral face.

Indeed, this fearful conclusion is reinforced by the fact that none of the major OECD countries pushing for such a Social Clause expect to be the defendants, instead of plaintiffs, in Social- Clause-generated trade-access cases. On the one hand, the standards (such as prohibition of child labour) to be included in the Social Clause to date are invariably presented as those that the developing countries are guilty of violating, even when some transgressions thereof are to be found in the developed countries themselves. Thus, according to a report in The Financial Times, a standard example used by the labour movement to garner support for better safety standards is a disastrous fire in a toy factory in Thailand where many died because exits were shut and unuseable. Yet, when I read this report, I recalled an example just like this (but far more disconcerting when you noted that the fatalities occurred in the richest country in the world) about a chicken plant in North Carolina where also the exits were closed for the same reason. Yet, the focus was on the poor, not the rich, country.

At the same time, the choice of standards chosen for attention and sanctions at the WTO is also clearly biased against the poor countries in the sense that none of the problems where many of the developed countries would be found in significant violation - such as worker participation in management, union rights, rights of migrants and immigrants - are meant to be included in the Social Clause. Symmetry of obligations simply does not exist in the Social Clause, as contemplated currently, in terms of the coverage of the standards.

The stones are thus to be thrown at the poor countries' glass houses by rich countries that build fortresses around their own. In fact, the salience which the 
Social Clause crusade has acquired in the US and Europe, and its specific contents, owe much to the widespread fear, evident during the NAFTA debate in the United States, that trade with the poor countries (with abundant unskilled labour) will produce unemployment and reductions in the real rages of the unskilled in the rich countries. The Social Clause is, in this perspective, a way in which the fearful unions seek to raise the costs of production in the poor countries as free trade with them threatens their jobs and wages.

\section{b. If not Social Clause, What Else?}

If this analysis is correct, then the idea of a Social Clause in the WTO is not appealing; and the developing countries' opposition to its enactment is justified. We would not be justified then in condemning their objections and unwillingness to go along with our demands as depravity and 'rejectionism'.

But if a Social Clause does not make good sense, is everything lost for those in both developed and developing countries who genuinely wish to advance their own views of what are 'good' labour standards? Evidently not.

It is surely open to them to use other instrumentalities such as nongovernmental organisation (NGO)-led educational activities to secure a consensus in favour of their positions. In fact, if your ideas are good, they should spread without coercion. The Spanish Inquisition should not be necessary to spread Christianity; indeed, the Pope has no troops. Mahatma Gandhi's splendid idea of nonviolent agitation spread, and was picked up by Martin Luther King, not because he worked on the Indian government to threaten retribution against others otherwise; it happened to be just morally compelling.

I would add that one also has the possibility of recourse to private boycotts, available under national and international law; they are an occasionally-effective instrument. They constitute a well-recognised method of protest and consensuscreation in favour of one's moral positions.

With the assistance of such methods of suasion, a multilateral consensus must be achieved on the moral and economic legitimacy of a carefully-defined labour standard (and formally agreed to at the ILO today in light of modern thinking in economics and of the accumulated experience of developmental and labour issues to date, and with the clear understanding that we are not just passing resolutions but that serious consequences may follow for follow-through by the signatory nations). The ILO is clearly the institution that is best equipped to create such a consensus, not the GATT/WTO, just as multilateral trade negotiations are conducted at the GATT, not at the ILO.

In turn, the annual ILO monitoring of compliance with ILO conventions is an impartial and multilateral process, undertaken with aid of eminent jurists across the world. Such a process, with changes for standing and for transparency, should be the appropriate forum for the annual review of compliance by nation 
states of such newly-clarified and multilaterally-agreed standards. Such monitoring, the opprobrium of public exposure, and the effective strengthening therewith of NGOs in the offending countries (many of which are now democratic and permissive of NGO activity) will often be large enough forces to prod these countries into corrective action.

In extraordinary cases where the violations are such that the moral sense of the world community is outraged, the existing international processes are available to undertake even coercive, corrective multilateral sanctions against specific countries to suspend their entire trading rights.

Thus, for instance, under UN embargo procedures, which take precedence over GATT and other treaties, South Africa's GATT membership proved no barrier to the embargo against it precisely because the world was virtually united in its opposition to apartheid. Even outside of the UN, the GATT waiver procedure has permitted 2/3rds of the Contracting Parties to suspend any GATT member's trading rights, altogether or for specific goods (and now, services).

I must add one final thought to assure those who feel their own moral view must be respected at any cost, even if others cannot be persuaded to see things that way. Even they need not worry under current international procedures. Thus, suppose that (say) American or French public opinion on an issue (as in the Tuna-Dolphin case for the former and the Beef-Hormone case for the latter) forces the government to undertake a unilateral suspension of another GATT member's trading rights. There is nothing in the GATT nor will there be anything in the WTO, which will then compel the overturning of such unilateral action. The offending Contracting Party (i.e. the one undertaking the unilateral action) can persist in a violation while making a compensatory offer of an alternative trade concession or the offended Party can retaliate by withdrawing an equivalent trade concession. Thus, unless one resents having to pay for one's virtue (since the claim is that 'our labour standard is morally superior'), this is a perfectly sensible solution even to politically-unavoidable unilateralism: do not import glass bangles made with child labour in Pakistan or India, but make some other compensatory trade concession. And remember that the grant of an alternative trade concession (or tariff retaliation) makes some other activity than the offending one more attractive, thus helping one to shrink the offending activity: that surely should be a matter for approbation rather than knee-jerk dismissal.

\section{REFERENCES}

Bhagwati, J. (1993) 'American Rules, Mexican Jobs', The New York Times (24 March).

Bhagwati, J. and R. Hudec (eds.) (1996), Fair Trade and Harmonization: Prerequisites for Free Trade? (MIT Press: Cambridge, Mass., forthcoming).

Bhagwati, J. and T.N. Scrinivasan (1996), 'Trade and the Environment: Does Environmental Diversity Detract from the Case for Free Trade?' in J. Bhagwati and R. Hudec (eds.) Fair Trade 
and Harmonization: Prerequisites for Free Trade? Vol. 1, Ch. 4 (MIT Press: Cambridge, Mass., forthcoming).

Levinson, A. (1996). 'Environmental Regulations and Industry Location: International and Domestic Evidence,' in J. Bhagwati and R. Hudec (eds.), Fair Trade and Harmonization: Prerequisites for Free Trade? Vol. 1, Ch. 11 (MIT Press: Cambridge, Mass., forthcoming). Wilson, J. (1996), 'Capital Mobility and Environmental Standards: Is There a Theoretical Basis for a Race to the Bottom?' in J. Bhagwati and R. Hudec (eds.), Fair Trade and Harmonization: Prerequisites for Free Trade? Vol. 1, Ch. 10 (MIT Press: Cambridge, Mass., forthcoming). 